\title{
$\mathrm{Ag}$ 및 탄소 나노윤활유의 제조 및 윤활특성 평가
}

\author{
최철 · 정미희 · 최영민* · 오제명 \\ 한국전력 전력연구원 전략기술연구소 전력소재그룹 \\ *부산대학교 공과대학 기계공학부
}

\section{Tribological Behavior of Lubricating Oil-Based Nanofluids Containing Ag and Carbon Nanoparticles}

\author{
Cheol Choi ${ }^{\dagger}$, Mi-Hee Jung, Young-Min Choi*, Jae-Myung Oh \\ Advanced Materials Research Group, Strategic Technology Laboratory, KEPRI, Taejon, 305-380 \\ *School of Mechanical Engineering, Pusan National University, Pusan, 609-735
}

(2008년 10월 6일 접수 : 2008년 10월 30일 최종수정 : 2008년 10월 31일 채택)

\begin{abstract}
Oil-based nanofluids were prepared by dispersing Ag, graphite and carbon black nanoparticles in lubricating oil. Agglomerated nanoparticles were dispersed evenly with a high-speed bead mill and/or ultrasonic homogenizer, and the surfaces of the nanoparticles were modified simultaneously with several dispersants. Their tribological behaviors were evaluated with a pin-on-disk, disk-on-disk and four-ball EP and wear tester. It is obvious that the optimal combination of nanoparticles, surfactants and surface modification process is very important for the dispersity of nanofluids, and it eventually affects the tribological properties as a controlling factor. Results indicate that a relatively larger size and higher concentration of nanoparticles lead to better load-carrying capacity. In contrast, the use of a smaller size and lower concentration of particles is recommended for reducing the friction coefficient of lubricating oil. Moreover, nanofluids with mixed nanoparticles of $\mathrm{Ag}$ and graphite are more suitable for the improvement of load-carrying capacity and antiwear properties.
\end{abstract}

Key words nanofluid, lubricating oil, friction coefficient, load-carrying capacity, anti-wear

\section{1. 서 론}

물이나 오일과 같은 열전달용 액상매체에 열전도도 특 성이 뛰어난 나노소재를 미량 분산시킴에 의해서 유체의 열전달 특성을 크게 향상시킬 수 있다는 것이 나노유체 (nanofluid)의 기본 개념이며 ${ }^{1)}$, 이것은 윤활매체의 윤활특 성 향상에도 응용될 수 있음이 보고되고 있다. ${ }^{2-9)}$ 즉, 액 상 매체에 분산된 극미세 나노분말은 유중에서의 불규칙 브라운 운동(Brownian motion)에 의해 고/액 계면에서의 열교환이 활성화되어 유체의 열전달 특성을 향상시키기 도 하지만 ${ }^{10)}$, 볼베어링, 결함부 치유(repairing effect) 및 금속/금속 마찰부 경도향상(surface hardness effect) 등의 효과에 의해 마찰계수를 낮추고 내마모 및 내하중 특성 을 향상시키는 것으로 알려져 있다. ${ }^{2-4)}$ 다만, 윤활유와 같 은 고점도 물질에서는 나노분말의 브라운 운동이 제한되 므로 직접적으로 유체의 열전도도나 대류열전달 특성을 크게 향상시키지 못함이 확인되고 있다. 그러나 나노분

Corresponding author

E-Mail : cchoi@kepri.re.kr (C. Choi)
말 첨가에 의해 윤활유의 마찰 및 극압특성이 대폭 향 상됨으로써, 에너지 효율 향상 외에도 마찰열의 발생을 근본적으로 감소시키고 회전윤활기기의 손상 및 윤활유 의 열적 산화를 방지할 수 있다.

나노분말 첨가에 의해 윤활유의 윤활특성이 향상될 수 있는 이론 및 실험적 가능성은 여러 연구자들에 의해 제 안되고 있지만, 나노분말을 오일에 장시간 안정되게 분 산시키는 기술의 확보가 나노윤활유 제조에 있어서 가장 큰 장애물로 작용하고 있다. ${ }^{12)}$ 즉, 전 세계적으로 나노 분말의 친유성 표면개질 및 분산/분산제에 대해서는 관 련 연구가 매우 미흡한 실정이다. 또한 나노분말을 윤활 유 첨가제로 사용하는 경우에 있어서, 분말의 조성, 크 기 및 농도가 윤활유의 분산성 및 윤활특성에 미치는 영 향에 대한 체계적인 연구결과가 보고되지 않고 있다.

본 연구에서는 상용 기어오일을 기반으로 그래파이트 및 카본블랙과 같은 탄소 나노소재와 $\mathrm{Ag}$ 금속분말을 이 용하여 분산성이 우수한 나노윤활유를 제조하였으며, 나 노분말의 제반 특성이 나노윤활유의 윤활특성에 미치는 영향을 비교 평가하였다. 


\section{2. 실험 방법}

\section{1 나노윤활유 제조}

나노윤활유 제조를 위하여 평균입도 $60 \mathrm{~nm}$ 이하의 그 래파이트, 카본블랙 및 $\mathrm{Ag}$ 금속 나노분말을 $0.05 ~ 1.0 \mathrm{vol} . \%$ 의 농도로 산업용 기어유(SK 슈퍼기어 EP220)에 분산 시켰다. 나노분말의 체적농도는 분말의 무게를 순밀도(true density)로 나누어 얻은 체적값으로 결정하였다. 실험에 사 용된 나노분말의 TEM 사진과 주요 물성을 Fig. 1과 Table 1에 정리하였다. 일반적으로 대기에 노출된 나노 분말은 수백 $\mathrm{nm}$ 수 $\mu \mathrm{m}$ 크기의 조대한 응집체(agglomerates)
로 존재하기 때문에 이것을 1차 입자 수준으로 분리시 키기 위해 노말헥산 $(96 \%$, Kanto Chemical) 또는 윤활유 (EP220)를 분산매로 하여 초음파분산기(UH-600SR, SMT) 와 비드밀(UAM015, Kotobuki)을 이용하여 습식분산하였 다. 또한 시간 경과에 따라 이웃 입자들과 재응집하여 침 전되는 나노분말 특성을 고려하여, 1 차 교반 후 분산성 과 분말입도 분석을 통해 결정된 분산제를 적용하여 친 유성 표면개질함으로써 나노분말의 장기적 분산성을 확 보하였다. 최적 분산제 결정을 위한 사전실험은 기계식 교반장치의 일종인 균질기(T25, IKA)를 이용하였으며, 30 분간 습식분산한 후, 분산성을 비교하였다.

Table 1. Properties of test materials for preparing nanofluids.

\begin{tabular}{ccccccc}
\hline $\begin{array}{c}\text { Chemical } \\
\text { Composition }\end{array}$ & $\begin{array}{c}\text { APS }^{*} \\
(\mathrm{~nm})\end{array}$ & $\begin{array}{c}\mathrm{SSA}^{* *} \\
\left(\mathrm{~m}^{2} / \mathrm{g}\right)\end{array}$ & $\begin{array}{c}\text { Crystal } \\
\text { Structure }\end{array}$ & Morphology & $\begin{array}{c}\text { Purity } \\
(\%)\end{array}$ & Maker \\
Graphite & 55 & $>60$ & hexagonal & spherical & 98.0 & $\begin{array}{c}\text { Nanostructured } \\
\text { \& Amorphous } \\
\text { Materials, USA }\end{array}$ \\
Carbon & 450 & - & - & & 99.0 & KCB, Korea \\
Black & 18 & 180 & - & spherical & 99.0 & \\
Ag & 58 & 38 & cubic & spherical & 90.0 & RIST, Korea \\
Ag & 7 & - & cubic & spherical & 99.9 & N\&A, USA \\
\hline$*$ APS : Average Particle Size, **SSA : Specific Surface Area & & & \\
\hline
\end{tabular}

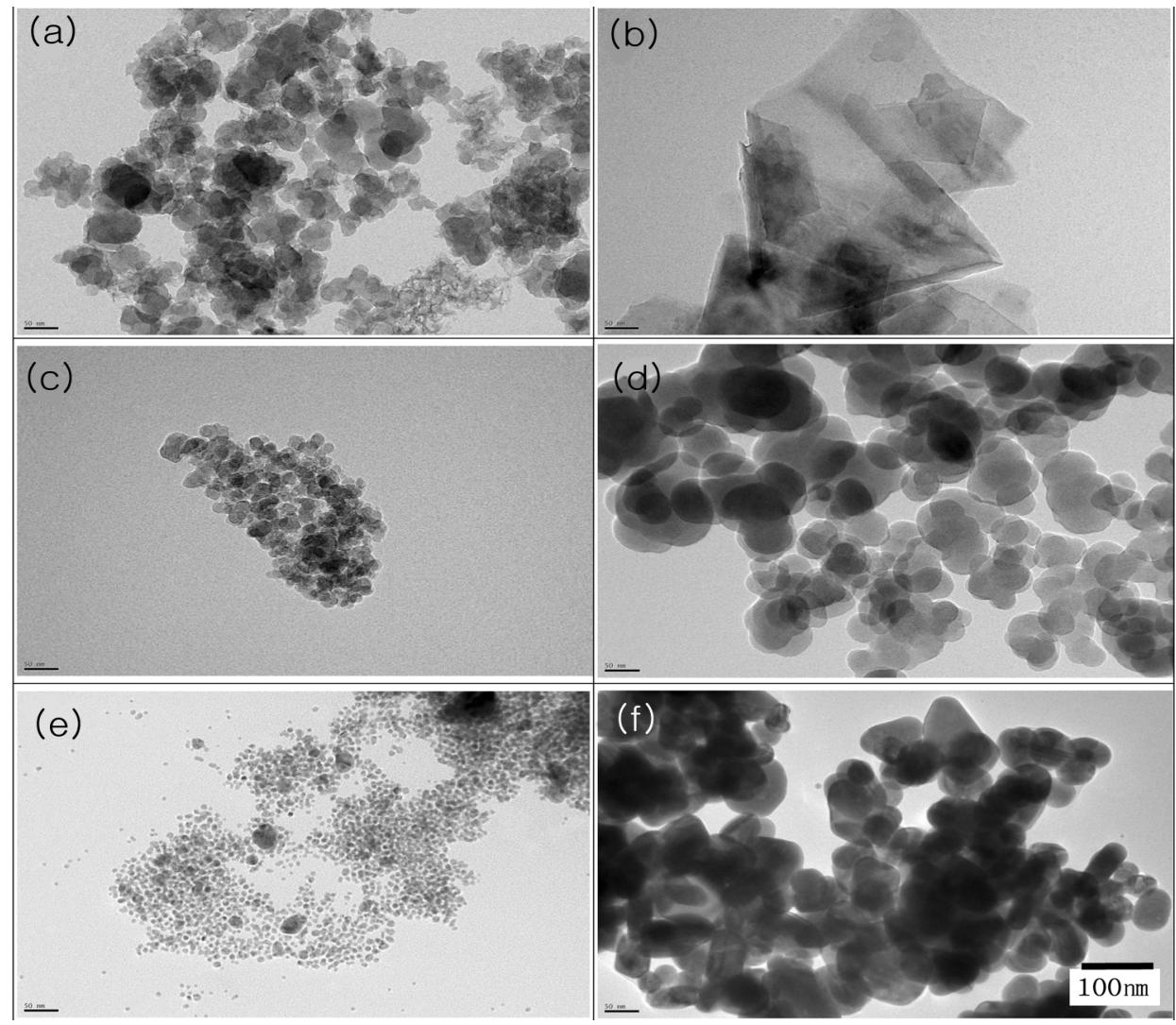

Fig. 1. TEM images of (a) $55 \mathrm{~nm}$, (b) $450 \mathrm{~nm}$ graphite, (c) $18 \mathrm{~nm}$, (d) $58 \mathrm{~nm}$ carbon black, (e) $7 \mathrm{~nm}$, (f) $50 \mathrm{~nm}$ Ag nanoparticles (magnification $\times 30,000$ ) 


\section{2 나노윤활유 윤활특성 평가}

나노윤활유의 극압 내하중성 및 내마모성을 평가하기 위하여 4볼 시험기(TE-92, Plint)를 사용하였다. 극압특성 은 ASTM D 2783 규격에 의거, 상온 및 $1760 \mathrm{rpm}$ 회전 속도 조건에서 하중을 변화시키면서 10 초 동안 시험하 였다. 내마모성 평가는 하중 $392 \mathrm{~N}$, 유온 $75^{\circ} \mathrm{C}$, 회전속 도 $1200 \mathrm{rpm}$ 조건에서 1시간씩 수행한 후, 볼의 마모직 경(wear scar diameter)을 측정하였다. 시험볼은 ANSI Standard Steel No. E-52100 기준으로 제조된, 직경 $12.7 \mathrm{~mm}$ 의 크롬 합금강을 사용하였다.

마찰특성은 자체 제작한 disk-on-disk 방식의 tribometer를 사용하여 측정하였다. 실험방법은 disk 회전수를 $1,000 \mathrm{rpm}$ ( 선속도 $1.36 \mathrm{~m} / \mathrm{s}$ )으로 고정하고, step-by-step 방식으로 하 중을 10 분마다 $200 \mathrm{~N}$ 씩 증가하여 $3,000 \mathrm{~N}$ 까지 실험하였 다. 마찰재와 상대재 모두 $\mathrm{GC} 200$ (회주철) 재료를 사용 하였으며, 겉보기 접촉면적은 $2.43 \mathrm{~cm}^{2}$ 이었다. Stribeck curve는 Fig. 2와 같은 pin-on-disk 방식의 장비(UMT$3 \mathrm{MT}, \mathrm{CETR})$ 를 이용하여 얻었으며, 하중 $4 \mathrm{~N}$ 조건에서 시료의 회전속도를 12 단계(1 2000 rpm)로 달리하면서 마 찰계수의 변화를 조사하였다.

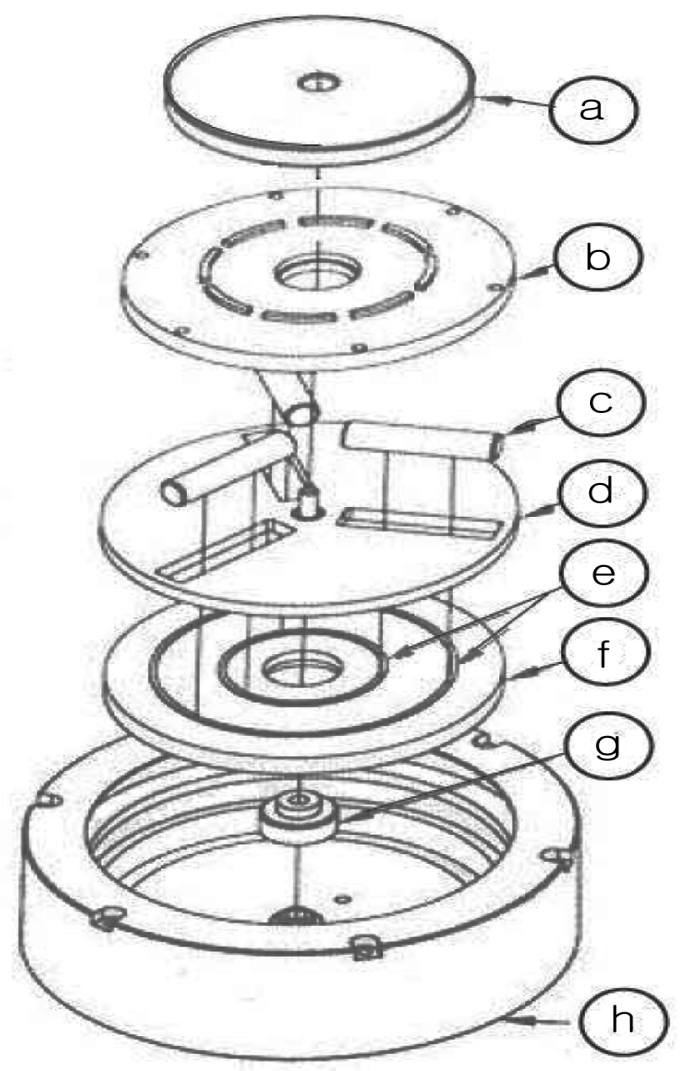

Fig. 2. Schematic diagram of pin-on-disk tribotester :(a) pressure plate, (b)(f) raceway disk, (c) roller, (d) spacer disk, (e) two raised concentric rails, (g) bearing, (h) liquid holder. The rollers (c) move between 2 pairs of rails (e) that are at different radii, and friction occurs between them.

\section{3 나노윤활유 물성평가}

합성된 나노윤활유는 근적외선을 이용하는 원심분리 방 식(LUMifuge, L.U.M. GmbH) 및 자연침강 방식(Turbiscan, Formulaction)의 2가지 평가장치를 이용하여 윤활유 내에 서 분말의 침강속도를 비교하고 장기 분산성을 평가하였 다. 또한 레오미터(AR550, TA)를 이용하여 온도와 전단 속도에 따른 나노윤활유의 정점도 변화를 평가하였다.

\section{3. 결과 및 고찰}

\section{1 나노윤활유 분산 및 점도특성}

\section{1 .1 분산 특성}

초음파 $(20 \mathrm{kHz}, 600 \mathrm{~W})$ 와 비드밀 $\left(\phi 0.05 \mathrm{~mm}, \mathrm{ZrO}_{2} \mathrm{Bead}\right.$, $7.6 \mathrm{~m} / \mathrm{s}$ )을 이용하여 제조된 $0.1 \mathrm{vol} \%$ 나노윤활유에 원심 력 $(\mathrm{x} 1147 \mathrm{~g})$ 을 부가하여 분말을 강제 침전시키면서 분산 성을 비교평가하였다(Fig. 3). 그림에서 카본블랙( $0.22 \mathrm{~g} /$ $\left.\mathrm{cm}^{3}\right)$ 나노윤활유는 크기에 무관하게 매우 안정된 분산성 을 보이지만, 그래파이트 $\left(\sim 0.26 \mathrm{~g} / \mathrm{cm}^{3}\right)$ 및 $\mathrm{Ag}\left(1 \sim 2 \mathrm{~g} / \mathrm{cm}^{3}\right)$ 나노윤활유는 분말의 크기가 증가할수록 분산성이 저하 됨을 알 수 있다. 특히, $\mathrm{Ag}$ 나노윤활유는 분말의 크기

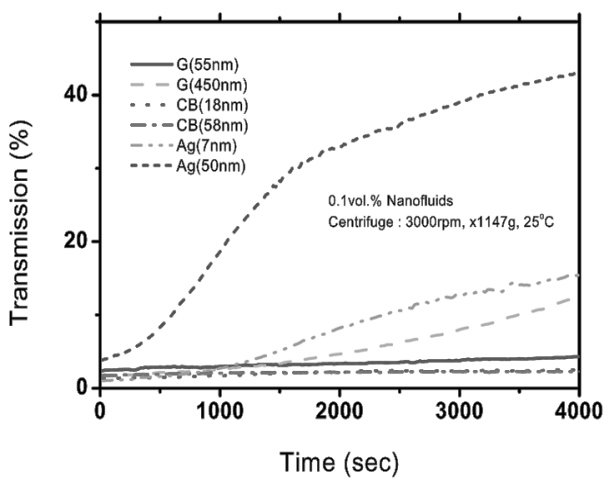

(a)

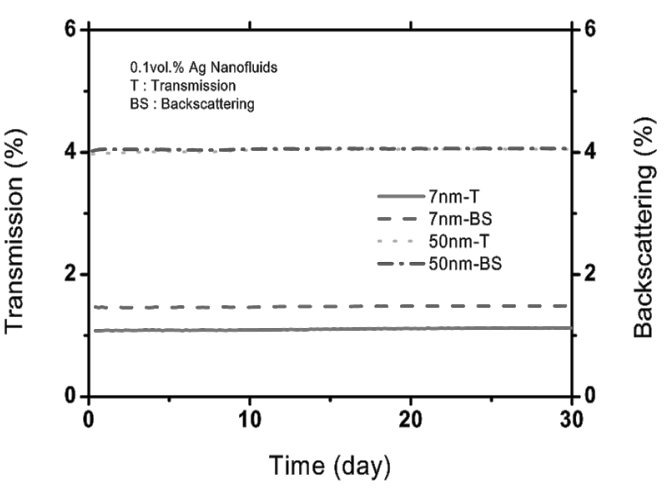

(b)

Fig. 3. Transmission-time curves for 0.1 vol. $\%$ graphite, carbon black and $\mathrm{Ag}$ nanofluids prepared with different particle size under (a) centrifugal force $(\times 1147 \mathrm{~g})$ and $(\mathrm{b})$ atmospheric pressure. 
가 $7 \mathrm{~nm}$ 정도로 매우 미세함에도 불구하고 탄소 나노소 재보다 밀도가 10 배 정도 높기 때문에 상대적으로 분산 성이 열악하게 나타난 것으로 생각된다. 즉, 동일 조건 에서 나노유체의 분산성은 유체에 분산된 나노분말의 밀 도에 크게 의존하며, 따라서 장기 분산성이 우수한 나노 윤활유 제조를 위해서는 가능한 저밀도 및 미세립의 분 말을 사용할 것이 권장된다. 또한 원심력에 의해서는 Fig. $3(\mathrm{a})$ 와 같은 침전거동을 보였지만, 대기압 조건에서는 모 든 시료에서 매우 안정된 분산성을 보였다. Fig. 3(b)에 Fig. 3(a)에서 가장 열악한 분산성을 보인 $\mathrm{Ag}$ 나노윤활 유의 대기압하에서의 자연침강에 의한 침전거동 변화를 보였는데, 근적외선 투과빔 및 반사빔 모두에서 1달동안 뚜렷한 침전거동을 확인할 수 없었다.

\subsection{2 점도 특성}

윤활유에 있어서 점도 특성은 마찰면에 충분한 윤활효 과를 제공하기 위해 매우 중요하다. 즉, 윤활유의 점도 가 낮으면 고하중 및 고속회전 조건에서 충분한 윤활막 형성이 어렵고, 너무 높으면 윤활유 순환펌프의 부하가 증가한다. 순수 윤활유(EP220)와 각 나노윤활유의 정점 도 값을 레오미터로 측정하여 비교하였는데, 모든 나노 윤활유가 전단속도에 무관하게 일정한 점도값을 보이는 뉴턴유체(Newtonian fluid) 거동을 보였으며 오차 범위 내에서 순수 윤활유와 거의 동일한 점도값 $(0.4814 \mathrm{~Pa} \cdot \mathrm{S})$ 을 가졌다(Fig. 4).

\section{2 마찰계수 평가}

완전 유체윤활(full film lubrication) 영역에서 각 나노 윤활유에 의한 마찰계수 저감효과를 평가하여 Fig. 5에

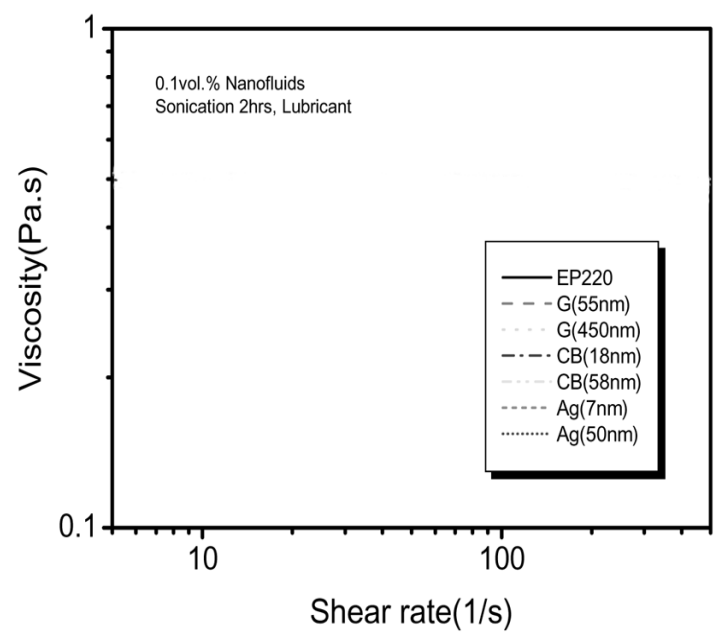

Fig. 4. Viscosity versus shear rate plot for 0.1 vol.\% graphite, carbon black and Ag nanofluids with different particle size at room temperature.
보였다. 동일 조성의 나노분말을 사용하더라도 사용한 분 말의 크기에 따라, 혹은 비슷한 분말 크기 조건에서도 분 말에 따라 마찰계수가 크게 달라짐을 알 수 있다. 즉, $\mathrm{Ag}$ 나노윤활유에서는 평균입도가 작은 분말을 사용할수 록 마찰계수가 낮게 나타났지만, 카본블랙 나노윤활유에 서는 정반대의 결과가 얻어졌다. 즉, 평균직경 $18 \mathrm{~nm}$ 의 매우 미세한 분말을 사용하여 제조한 나노윤활유는 $58 \mathrm{~nm}$ 시료에 비해 마찰계수가 $50 \%$ 이상 증가하였다. 또한 그 래파이트 나노윤활유에서처럼 너무 큰 분말 $(450 \mathrm{~nm})$ 의 사 용도 마찰계수를 낮추는데 효과적이지 않았다.

나노유체를 열전달 매체로 사용할 경우에는 첨가되는 분말의 크기가 작을수록 열전도도 특성이 향상되지만, 윤 활유 첨가제로서 분말을 사용하는 경우에는 분말 소재별 로 최상의 윤활특성을 가지기 위한 최적 입도 조건이 존 재하는 것으로 생각된다. 일반적으로 탄소 계열 나노윤 활유에 비해 금속/합금 나노윤활유는 동일 농도와 입도 조건에서 마찰계수가 상대적으로 높다. 또한 가장 낮은 마찰계수를 보이는 최적 분말 크기도 수 $\mathrm{nm}$ 정도로, 탄 소 나노소재에 비하여 매우 작다. 이것은 탄소 나노소재 와 금속 분말 사이의 경도 값 차이에서 비롯되는 것으 로 생각된다. 즉, 고경도 재료일수록 보다 작은 크기의 분말에서 보다 우수한 마찰저감 효과가 얻어지는 것으로 판단된다. 탄소 나노소재와 같이 경도 값이 낮은 재료는 유체윤활 영역(저하중 영역)에서 일정 수준 이하의 너무 작은 크기를 가지면 마찰계수가 오히려 상승하지만, $\mathrm{Ag}$ 와 같이 상대적으로 경도가 높은 재료에서는 $7 \mathrm{~nm}$ 정도 의 매우 미세한 크기 조건에서 최상의 마찰특성을 보인

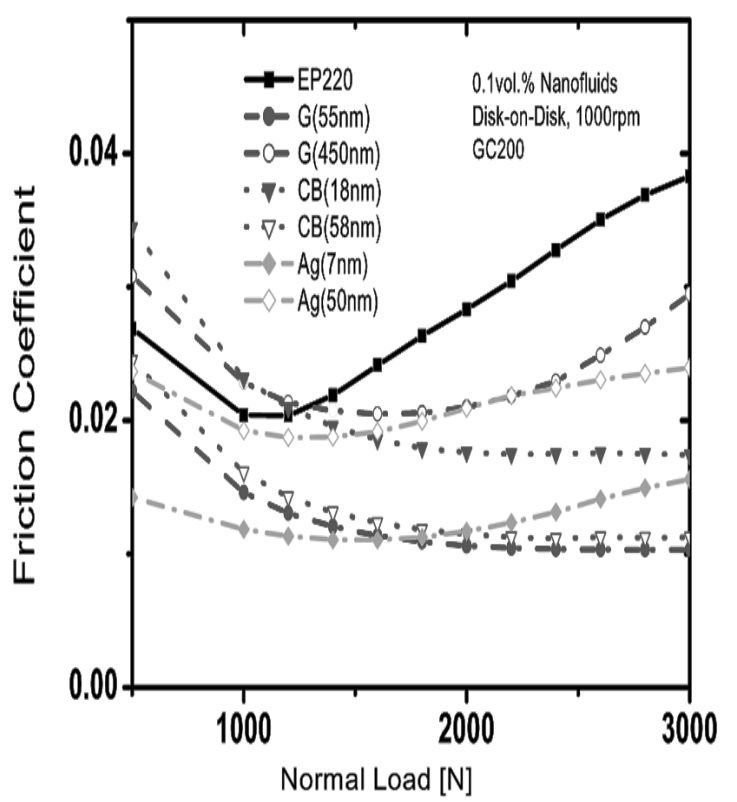

Fig. 5. Friction coefficient of graphite, carbon black and $\mathrm{Ag}$ nanofluids prepared with different particle size. 


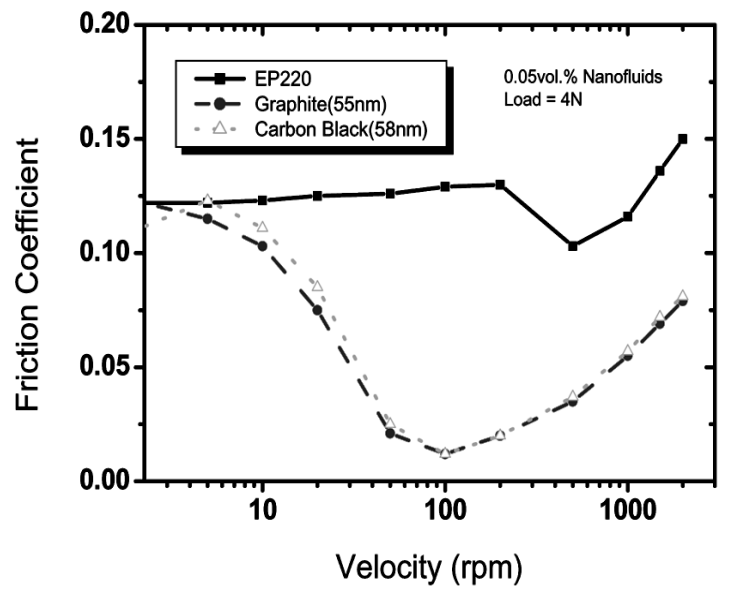

Fig. 6. Stribeck curves of graphite $(55 \mathrm{~nm})$ and carbon black $(58 \mathrm{~nm})$ nanofluids for $0.05 \%$ particle volume concentration.

다. 오히려 고경도 소재는 입자의 크기가 증가할수록 금속 /금속 마찰부의 마찰과 마모를 유도할 수 있기 때문에, 분말의 크기와 농도를 저경도 재료보다 낮게 조절할 것 이 요구된다.

그래파이트 및 카본블랙 나노윤활유의 Stribeck 곡선을 순수 윤활유와 비교하여 Fig. 6에 보였다. 그림에서 2가 지 탄소 나노윤활유는 유체윤활 영역에서 $0.05 \mathrm{vol} . \%$ 의 저농도 조건으로도 순수 윤활유에 비해 마찰계수를 최대 90\% 이상 저감시킬 수 있었다. 그러나 시료의 회전속도 가 줄어들어 실질적인 경계윤활(boundary lubrication) 영 역에 접어들면 순수 윤활유와 오차범위 내에서 마찰계수 차이를 보이지 않는다. 실제로 탄소 나노윤활유의 경우, 유체윤활 영역에서 시료의 분말 농도를 $0.5 \mathrm{vol} . \%$ 까지 늘 려도 마찰계수는 크게 감소하지 않았으며, 오히려 금속 나노윤활유의 경우에는 순수 윤활유보다 마찰계수가 증 가하는 경향을 보이므로 마찰특성 향상을 위해서는 기본 적으로 저농도, 미립자 분말을 사용하는 것이 권장된다.

\section{3 극압 및 내마모 특성}

본 실험에서 사용한 윤활유는 산업용 기어유(EP220)이 며, 기어는 극압(extream pressure;EP) 조건에서 운전되기 때문에 마찰특성보다는 내하중 및 내마모(anti-wear) 특 성이 보다 중요하다. 그래파이트 및 $\mathrm{Ag}$ 나노윤활유를 4 볼 마멸장치(four ball wear tester)를 이용하여 내하중 (four ball EP) 시험한 결과를 Fig. 7에 보였다.

$1.0 \mathrm{vol} . \% \mathrm{Ag}$ 나노윤활유의 경우, 평균입도 $7 \mathrm{~nm}$ 시료 에서는 융착점(welding point)이 $315 \mathrm{kgf}$ 로 순수 윤활유 $(250 \mathrm{kgf})$ 보다 크게 증가하지 않지만, $50 \mathrm{~nm}$ 시료는 $500 \mathrm{kgf}$ 로 순수 윤활유의 2 배에 해당하는 매우 높은 값 을 보였다. 이것은 마찰계수 시험 결과와 정반대되는 것 으로, 내하중성 향상을 위해서는 너무 작은 크기의 분말

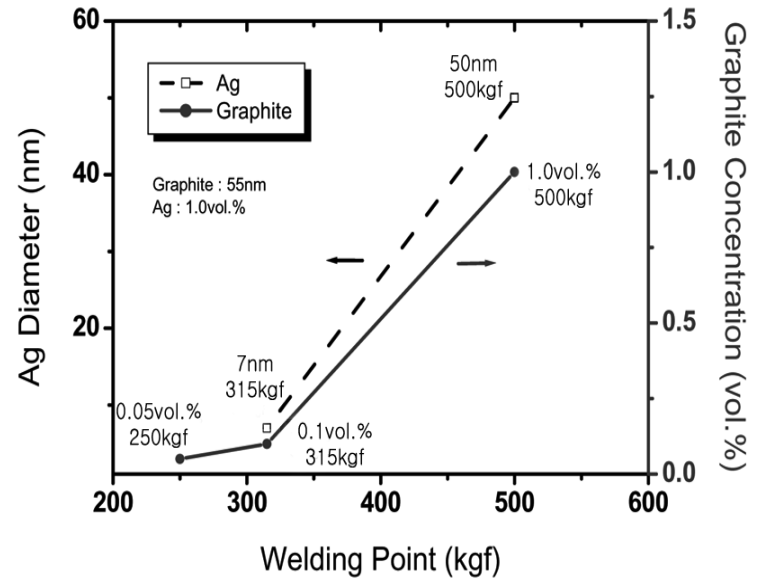

Fig. 7. Effect of Ag nanoparticle diameter and graphite concentration on welding point of nanofluids.

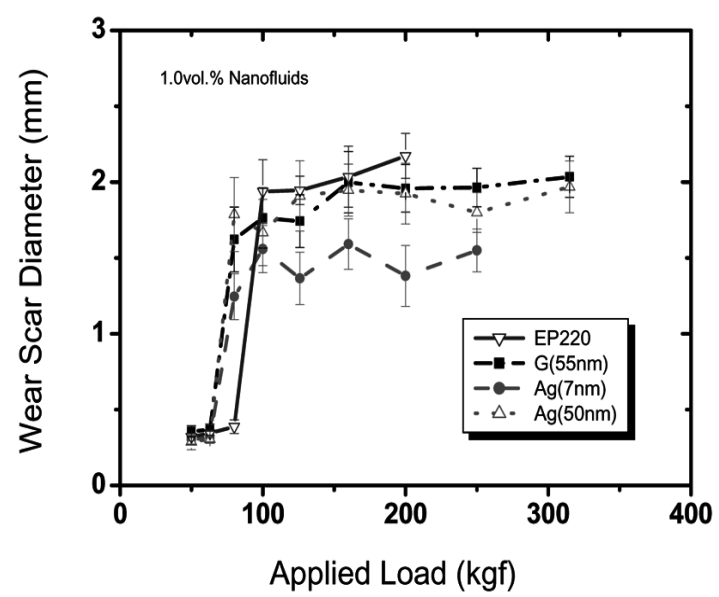

Fig. 8. Wear scar diameter as a function of applied load for EP220 and nanofluids containing 1.0 vol.\% of graphite and Ag particles.

사용이 바람직하지 않음을 의미한다. 또한 평균입도가 $55 \mathrm{~nm}$ 인 그래파이트 나노윤활유를 농도별로 내하중 시험 한 결과, 분말의 농도가 $0.1 \mathrm{vol} . \%$ 까지는 뚜렷한 내하 중성 향상을 관찰할 수 없었지만, $1.0 \mathrm{vol} . \%$ 까지 농도를 증가시키자 $500 \mathrm{kgf}$ 의 높은 융착점을 보였다. 따라서 나 노분말을 첨가하여 윤활유의 내하중성을 증가시키기 위 해서는 상대적으로 고농도 시료가 요구됨을 알 수 있다.

상기 3 가지 나노윤활유에 대하여 내하중 시험을 실시 한 후, 볼의 마모직경을 측정하여 Fig. 8에 보였다. Fig. 9에 보인 시료의 마모흔적으로부터 $7 \mathrm{~nm} \mathrm{Ag}$ 나노윤활유 의 마모 직경은 $50 \mathrm{~nm}$ 시료의 그것보다 $20 \%$ 이상 작 음을 알 수 있다. 실제 4볼 마멸(four ball wear) 시험 결과도 각각 $0.33 \mathrm{~mm}$ 및 $0.41 \mathrm{~mm}$ 로 나타남으로써 비슷 한 경향을 보였다. 이것은 $7 \mathrm{~nm}$ 시료의 융착점이 $50 \mathrm{~nm}$ 시료에 비해 크게 낮은 것과 대조적이다. 또한 Fig. 7에 서 우수한 내하중 특성 $(500 \mathrm{kgf})$ 을 보인 $1.0 \mathrm{vol} \%$ 그래 파이트 나노윤활유도 마모직경 $(0.55 \mathrm{~mm})$ 은 순수 윤활유 

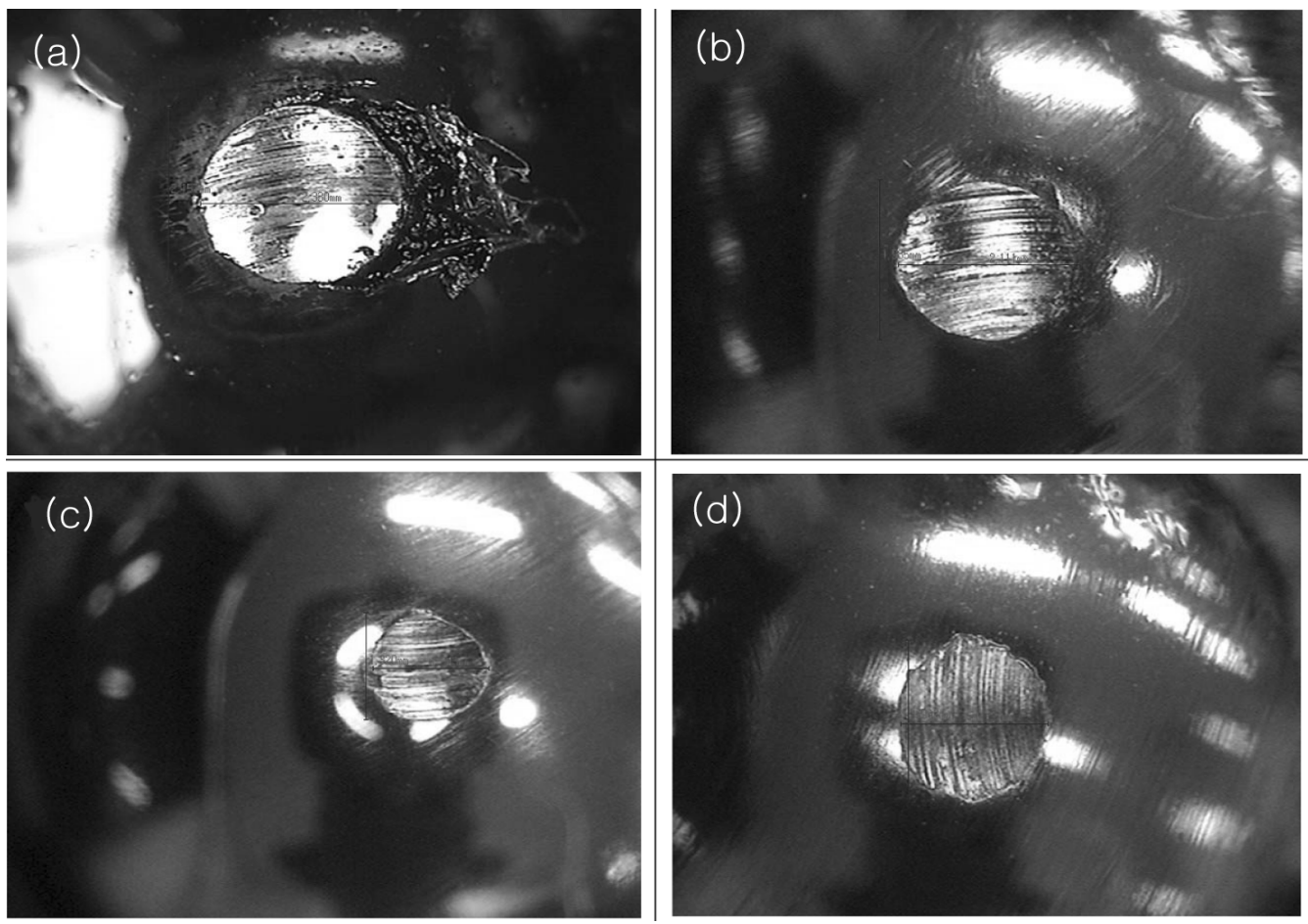

Fig. 9. Wear scar morphology of the ball after four ball EP test in the oil (a) without nanoparticle and with (b) $55 \mathrm{~nm}$ graphite, (c) $7 \mathrm{~nm} \mathrm{Ag}$, (d) $50 \mathrm{~nm} \mathrm{Ag} \mathrm{nanoparticles} \mathrm{at} \mathrm{a} \mathrm{particle} \mathrm{volume} \mathrm{concentration} \mathrm{of} 1.0 \%$.

$(0.56 \mathrm{~mm})$ 와 큰 차이를 보이지 않음으로써 내마모 특성 향상 효과는 없는 것으로 확인되었다(Fig. 9). 즉, 시료 의 내하중성이 뛰어나다고 해서 내마모 특성까지 항상 우 수한 것은 아니며, 2 가지 특성 사이의 조화를 이룰 수 있는 분말 크기 및 농도 조건의 제시가 필요하다. 본 연 구에서는 평균입도 $7 \mathrm{~nm} \mathrm{Ag}$ 나노윤활유의 뛰어난 내마 모성과 그래파이트 나노윤활유의 내하중성을 함께 얻기 위하여 $1.0 \mathrm{vol} . \%$ 그래파이트, $\mathrm{Ag}$ 나노윤활유 및 순수 윤 활유(EP220)를 2:1:1의 비율로 혼합하여 시료를 제조한 후 동일 조건으로 내마모성과 내하중성을 평가한 결과, 마모직경은 $0.405 \mathrm{~mm}$, 융착점은 $500 \mathrm{kgf}$ 로 두 가지 특 성을 모두 살릴 수 있음을 확인하였다.

\section{4. 결 론}

2가지 탄소 나노소재 및 $\mathrm{Ag}$ 금속 나노분말을 이용하 여 나노윤활유를 제조하고 이들의 마찰계수, 내하중 및 내마모 특성을 조사하였다. 그 결과, 각각의 특성을 최 적화하는 나노윤활유 조성이 모두 다르게 나타났으며, 따 라서 적용하고자 하는 운전 조건에 따라 제조 조건을 달 리해야 할 것으로 판단되었다.

마찰계수는 상대적으로 저농도 및 미세립 분말을 함유 한 윤활유에서 높게 나타났으며, 분말의 경도 값이 높을 수록 최적 분말 크기와 농도가 줄어들었다. 이와 대조적
으로 나노윤활유의 내하중 특성은 상대적으로 고농도 및 조대립 분말 조건에서 높게 나타났으며, 그러나 내마모 특성은 분말의 크기가 증가 할 수록 저하됨으로써 두가 지 특성 사이의 조화가 요구되었다. 즉, 평균입도 $7 \mathrm{~nm}$ $\mathrm{Ag}$ 시료는 뛰어난 내마모 특성을 보였으나 내하중 특성 은 낮았으며, $55 \mathrm{~nm}$ 그래파이트 나노윤활유는 순수 윤 활유의 2 배에 해당하는 높은 내하중성을 보였으나 순수 윤활유와 비교하여 내마모 특성 향상효과가 나타나지 않 았다. 그러나 상기 두 시료를 1:2 비율로 혼합할 경우, 내하중성과 내마모성을 동시에 높일 수 있음을 확인하였 다.

\section{감사의 글}

본 연구는 전력기반조성사업센터와 한국전력공사가 지 원하는 전력산업연구개발사업(기금-312)의 연구비 지원으 로 수행되었으며, 이에 감사드립니다.

\section{참 고 문 헌}

1. P. Keblinski, J.A. Eastman, D.G. Cahill, Materials Today, 8, 36 (2005).

2. Y.Y. Wu, W.C. Tsui and T.C. Liu, Wear, 262, 819 (2007).

3. H.D. Huang, J.P. Tu, L.P. Gan and C.Z. Li, Wear, 261, 140 (2006). 
4. S. Tarasov, A. Kolubaev, S. Belyaev, M. Lerner and F. Tepper, Wear, 252, 63 (2002).

5. A. Hernandez Battez, R. Gonzalez, J.L. Viesca, J.E. Fernandez, J.M. Diaz Fernandez, A. Machado, R. Chou and J. Riba, Wear, 265, 422 (2008).

6. E. Fernandez Rico, I. Minondo and D. Garcia Cuervo, Wear, 262, 1399 (2007).

7. Z.S. Hu, R. Lai, F. Lou, L.G. Wang, Z.L. Chen, G.X. Chen and J.X. Dong, Wear, 252, 370 (2002).
8. W. Liu and S. Chen, Wear, 238, 120 (2000).

9. Q. Sunqing, D. Junxiu and C. Guoxu, Wear, 230, 35 (1999).

10. S.P. Jang and S.U.S. Choi, Appl. Phys. Lett., 84, 4316 (2004).

11. X. Li, Z. Cao, Z. Zhang and H. Dang, Appl. Surf. Sci., 252, 7856 (2006). 